Ann. Biol. anim. Bioch. Biophys., 1979, 19 (4 B), 1153-1178.

\title{
The role of the mesonephros in the development of the sheep fetal ovary
}

\author{
par L. ZAMBONI, Jacqueline BÉZARD *, P. MAULÉON * \\ Deparfment of Pathology, Harbor-UCLA Medical Center, Torrance, California 90509. \\ and University of California School of Medicine, Los Angeles, USA. \\ * Physiologie de la Reproduction, I.N.R.A., Nouzilly 37380 Monnaie, France.
}

Summary. Sexually indifferent gonads, ovaries and mesonephroi of sheep embryos and fetuses from day 24 of development through term (day 145) were studied by high resolution light microscopy and electron microscopy.

From day 24 to at least day 58, the sexually indifferent gonads and the ovaries are massively invaded and colonized by cells mobilized from a peculiar nephron situated in the proximal third of the mesonephros and referred to, because of its large size, as « giant 》. The mobilization process occurs simultaneously with the involution of the giant nephron, and involves the mesangial and epithelial cells of the glomerulus and, in late stages, also the epithelial cells of the walls of the excretory tubules. At first sporadically and, then, in the form of a prominent, compact cellular mass, these cells leave their sites of origin and, advancing along cranio-caudal and dorso-ventral directions, invade the gonads. Here the mesonephric cells establish a close and permanent associative relationship with the germinal cells, also seeding the gonads at these times. During sequential stages of ovarian development, the relationship between mesonephric and germinal cells assumes characteristics of increasing organization ; at first, it involves isolated cells, then cellular clusters and, ultimately, the ovigerous cords, elongated formations of mesonephric and germinal cells lined by a basal lamina from which follicles eventually develop.

Our observations demonstrate that, in the sheep, the mesonephros plays a fundamental role in the morphogenesis of the ovary as the source of the follicle cells and as one of the organizers of specific ovarian structures.

\section{Introduction.}

The origin of the ovigerous cords which form in the fetal ovary prior to follicle development and that of their somatic cell components, the precursors of the follicle cells, are two of the most confusing and unresolved aspects of mammalian embryology.

For many authors (Allen, 1904 ; Brambell, 1927, : Everett, 1943 ; Bookhout, 1945 ; Gillman, 1948, Van Wagenen and Simpson, 1965 ; Weakley, 1969 ; Gondos, 1969 ; Pelliniemi, 1975), the ovigerous cords and their somatic elements have a mesothelial 
origin. These authors maintain that cord formation results from the proliferative activity of the mesothelial cells lining the surface of the ovary; the proliferated cells would deepen into the subjacent stroma and would surround the germinal cells, organizing into cord-like structures. At least two waves of proliferation are believed to take place. The first would occur in the sexually indifferent gonad and would result in the formation of primary or medullary cords destined to undergo regression. The second wave, said to take place after sexual differentiation, would produce secondary or cortical cords from which the definitive follicles develop.

Other authors (Felix, 1912 ; Fishel, 1930 ; Gruenwald, 1942 ; Torrey, 1945 ; Pinkerton et al., 1961 ; Gropp and Ohno, 1966 ; Peters and Pedersen, 1967 ; Merchant, 1975) maintain that the ovigerous cords develop from a prominent blastema of somatic and germinal cells situated in the center of the ovary; they would form at the time this cellular mass becomes cleaved by invading septa of connective tissue and blood vessels. However, the origin of the somatic cells of the blastema remains to be determined. Felix (1912), Peters and Pedersen (1967) and Pinkerton et al. (1961) maintained that they derive from the mesenchymal cells of the ovarian stroma, Gruenwald (1942) and Torrey (1945) claimed that they originate from the surface mesothelium, and Gropp and Ohno (1966) postulated that they might have a mesonephric origin ; according to Merchant (1975), the blastema is an admixture of all somatic cell types present in and around the ovary, i.e., surface mesothelial, mesenchymal and mesonephric cells.

An intermediate position between the above theories was held by Witschi (1951, 1956, 1962). This author supported the concept of two different generations of cords, but claimed that those of the first, the medullary cords, derive from a cellular blastema of mesonephric origin, and those of the second, the cortical cords, from the surface mesothelium.

A third hypothesis is based on the observation that the ovigerous cords are often continuous with the refe ovarii, a network of tubules extending between the gonad and the mesonephros. Some authors claimed that the rete has an ovarian origin and derives from either the mesenchyme in the hilus of the ovary (Wichmann, 1912) or the mesothelial cells on the surface of the organ (Allen, 1904 ; Felix, 1912 ; Wilson, 1926 ; Gillman, 1948). Others (Waldeyer, 1870 ; Janosik, 1885 ; von Kölliker, 1898 ; von Winiwarter, 1900 ; von Winiwarter and Sainmont, 1908) maintained instead that the refe has a mesonephric origin and that it extends from the capsule of the mesonephric glomeruli into the ovary where it connects with the inner tips of the ovigerous cords streaming from the surface of the organ. These early observations were expanded recently by Byskov and Lintern-Moore (1973) who showed that, in the mouse, the rete originates from the region of the Wolffian duct and consists of three main segments, the extraovarian, connecting and intraovarian rete ; these authors showed also that, in their intraovarian portions, the rete tubules envelop the germinal cells and, at the time of follicle formation, contribute their somatic cells to the walls of the definitive follicles. On the basis of these observations, the authors concluded that the follicle cells derive from the rete ovarii and have a mesonephric origin.

The many unresolved aspects concerning the origin of the follicle cells prompted us to perform a detailed study of fetal ovarian morphogenesis at closely spaced inter- 
vals of development, from the genital ridge stage to term. To assess in the best possible fashion the relationship which may exist between the developing ovary and the mesonephros, the sheep was selected as the animal of choice since the embryos and fetuses of this animal are characterized by prominent mesonephroi (Brenner, 1916).

\section{Materials and methods.}

Sexually indifferent gonads, ovaries and mesonephroi of 48 sheep embryos and fetuses from artificially inseminated ewes of proven fertility were used. The earliest age studied was 24 days of fetal life and the most advanced, 145 days (term development). Nineteen embryos were obtained prior to sexual differentiation of the gonad which, in the sheep, can be detected at day 31 of fetal life.

The organs were fixed in 2.5 p. 100 glutaraldehyde in $0.1 \mathrm{M}$ cacodylate buffer, either by vascular perfusion or by immersion, post-fixed in $\mathrm{OsO}_{4}$ and embedded in Epon 812. The gonads of embryos and fetuses from day 24 to 78 of fetal life were excised and embedded together with their mesonephroi, or remnants thereof; this could not be done in older fetuses since their ovaries were too large to be embedded with the additional organs. The tissue blocks were serially sectioned for light microscopy, or electron microscopy, or both in alternate fashion. For each stage of development, one gonad was sectioned along a longitudinal plane, and the contralateral, along a transverse plane. Because of the complexity of the problem and the large dimensions of the organs, the study was performed primarily by high resolution light microscopy. The sections were cut at a thickness of approximately 1.0 micron, stained with an aqueous solution of Toluidine blue, and studied and photographed with a Zeiss Ultraphot or Photomicroscope. The thin sections for electron microscopy were stained with lead hydroxide and examined with a Hitachi HU11E microscope.

\section{Observations.}

In 24-day-old embryos, the youngest of our series, the rudiment of the gonad appeared as an elongated ridge on the antero-medial surface of the mesonephros (fig. 1). The ridge was delimited by a single layer of mesothelial cells and consisted of a primitive stroma containing undifferentiated mesenchymal cells, and a few primordial germinal cells beginning to colonize the area.

The mesonephros was voluminous and characterized by an impressive array of nephrons (fig. 2). The glomeruli occupied a ventral position and were aligned cranio-caudally over one another through the entire length of the organ (fig. 2) ; they were separated from the dorsal aspect of the genital ridge only by thin-walled vascular lacunae (fig. 1). The excretory tubules departed from the dorsal hemispheres of the glomeruli (fig. 2) and, after courses of considerable length, emptied into large collecting tubules draining into the Wolffian duct.

While the caudal two-thirds of the mesonephros contained nephrons of a conventional size and morphology (fig. 2) similar to those described by Leeson (1960) in the rabbit and by De Martino and Zamboni (1966) in the human, the cranial third was 
occupied entirely by an extremely large and complex nephron (fig. 3) which, owing to its size, is referred to in the literature as "giant " (Brenner, 1915 ; Davies and Davies, 1950). This structure, which is present also in the mesonephroi of the cow and the deer (Brenner, 1915), consisted of a very long, prominent glomerulus and a large number of excretory tubules (fig. 3). The extensive capillary bed of the giant glomerulus was alimented by numerous arterioles on the dorsal side, and drained into numerous, thin-walled venules on the ventral side. The capillary walls (fig. 4) were thin and consisted of an inner layer of attenuated endothelial cells, a delicate basal lamina, and an outer investment of epithelial cells, the visceral epithelium, provided with discrete foot processes. The cell population of the capillaries included also sparse mesangial cells, often displaying an intense affinity for the Toluidine blue and a very high electron density (fig. 4). The glomerulus was delimited by a thin capsule of attenuated epithelial cells, the capsular epithelium, resting on a basal lamina.

In the sheep, the regression of the mesonephros begins around days 24-26 of fetal life. The involution of the organ initiated in the proximal region and then spread distally affecting different nephrons at different times. While the involution of the nephrons in the distal thirds occurred as described in other species (rabbit, Bernier and Beaumont, 1964 ; human, De Martino et al., 1977), the regression of the giant nephron had unique features in that it was accompanied by a massive and sustained mobilization of glomerular and tubular cells which migrated outside the mesonephros, invaded the sexually indifferent gonad and the ovary, and differentiated into follicle cells. Thus, the phenomena associated with the regression of the giant nephron must be considered together with the changes occurring in sequential stages of ovarian development.

\section{Twenty-four through 29 days of fetal life.}

The giant glomeruli of embryos at these stages of development were in initial phases of involution. Their capillaries exhibited increased numbers of mesangial cells, narrowing of the lumina, and diffuse thickening of the walls (fig. 5). In many areas on the ventral aspect of the glomerulus, the capsule was effaced or missing altogether, resulting in the establishment of anatomical continuities between intraand extraglomerular compartments (figs 5 and 6). These channels were crowded

FIG. 1. - Cross-sectioned genital ridge of a 24-day-old embryo showing the close topographic relationship between the ventral aspect of a mesonephric glomerulus and the dorsal margin of the genital ridge. $1 \mu$ thick, Tolvidine blue stained section $\times 250$.

FIG. 2. - A longifudinal view of the middle third of the mesonephros occupied by conventional glomeruli surrounded dorsally by excretory and collecting tubules. Twenty-four-day-old embryo. $1 \mu$ thick. Toluidine blue stained section $\times 56$.

FIG. 3. - A longitudinal view of the giant nephron which occupies the whole cranial third of the sheep mesonephros. The enormous capillary tuft (shown here only partially) and the numerous excretory fubules along the dorsal aspect of the glomerulus are clearly visible. $1 \mu$ thick, Toluidine blue stained section $\times 150$. 

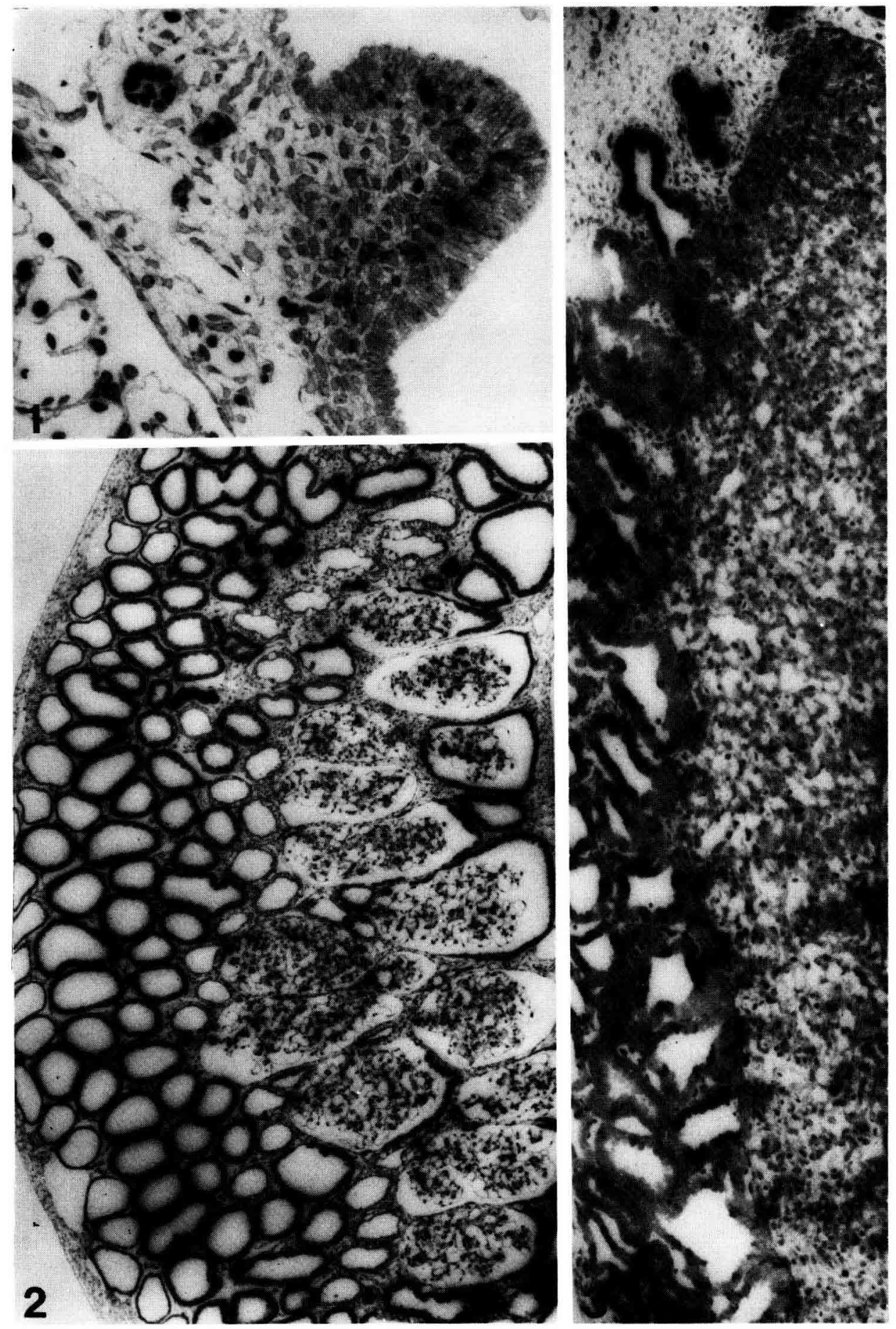
mostly by mesangial cells, identifiable by their tinctorial and electron density characteristics (figs 5 and 6), and by a few visceral epithelial cells, recognizable because of their numerous, slender microvilli (fig. 6), in the process of egressing from the glomerulus. All migrating cells displayed highly irregular profiles and presence of numerous pseudopodia (fig. 6), features which indicated that their migration occurred by ameboidism. Outside the glomerulus, the mobilized cells congregated in small clusters (fig. 5) which, in serial planes of sections, could be seen throughout the mesenchyme caudal and ventral to the giant glomerulus, all the way into the genital ridge. Here, the colonizing mesonephric cells dispersed randomly throughout the stroma establishing close association with the primordial germ cells (fig. 7) ; they surrounded the latter over most of their surfaces, the plasma membranes of the two cells being intimately apposed in a parallel fashion (fig. 7).

Thirty-one through 34 days of fetal life.

Sexual differentiation of the gonad was detected at day 31 of fetal life. The newly differentiated ovary appeared as a voluminous, elliptical organ protruding into the coelomic cavity with its curved ventral surface (fig. 8) ; the ovary was attached to the mesonephros along its dorsal margin as well as its proximal and distal poles where the connection was maintained through two pedunculi, the upper extending up to the region of the giant nephron (fig. 8), and the lower, down to the inferior third of the mesonephros.

The giaht glomeruli of fetuses at these stages of development all showed signs of advanced infolution. The capillary bed was considerably reduced and the vessels displayed ganeralized narrowing and obliteration of their lumina (figs 8 and 9), infolding and fragmentation of the basal laminae, and accumulation of collagen along the wqlls. The discontinuities of the capsule on the ventral aspect of the giant glomerulus were more numerous and wider than in previous stages, leaving long stretches of fapillary tufts naked and exposed directly to the surrounding mesenchyme (figs $\&$ and 9). The mobilization of mesangial and epithelial cells was more pronounced thah in previous stages and occurred in a more organized fashion. The cells egressed from the giant glomerulus in larger numbers and organized to form delicate trabeculae (fig. 9) which, in 34-day-old fetuses for the first time appeared

FIG. 4. - The ultrastructural appearance of the capillaries of the giant glomerulus in a 24-day-old embryo, prior to onset of involution of the mesonephros. At this stage, the mesangial cells $(M)$ are sparse and only one of them, identifiable for the high electron density of its cytoplasm, is present in the area. Note the thinness of the capillary wall and the discrete foot processes of the visceral epithelial cells (VE). The arrow points to an endothelial cell (E) in mitosis $\times 4,200$.

FIG. 5. - Early stage of involution of the giant glomerulus in a 28-day-old embryo. The capillary walls are thickened (compare with figs. 1 and 4) and the mesangial cells, identifiable for their intense affinity for the Toluidine blue, have increased in number. The asterisks delineate an area on the ventral aspect of the glomerulus where the capsule (C) is missing and the glomerular structures communicate directly with the outside mesenchyme. The channel is crowded by numerous mesangial and epithelial cells egressing from the glomerulus : a few of them can be discerned also in the periglomerular mesenchyme. $1 \mu$ thick, Tolvidine blue stained section $\times 520$. 


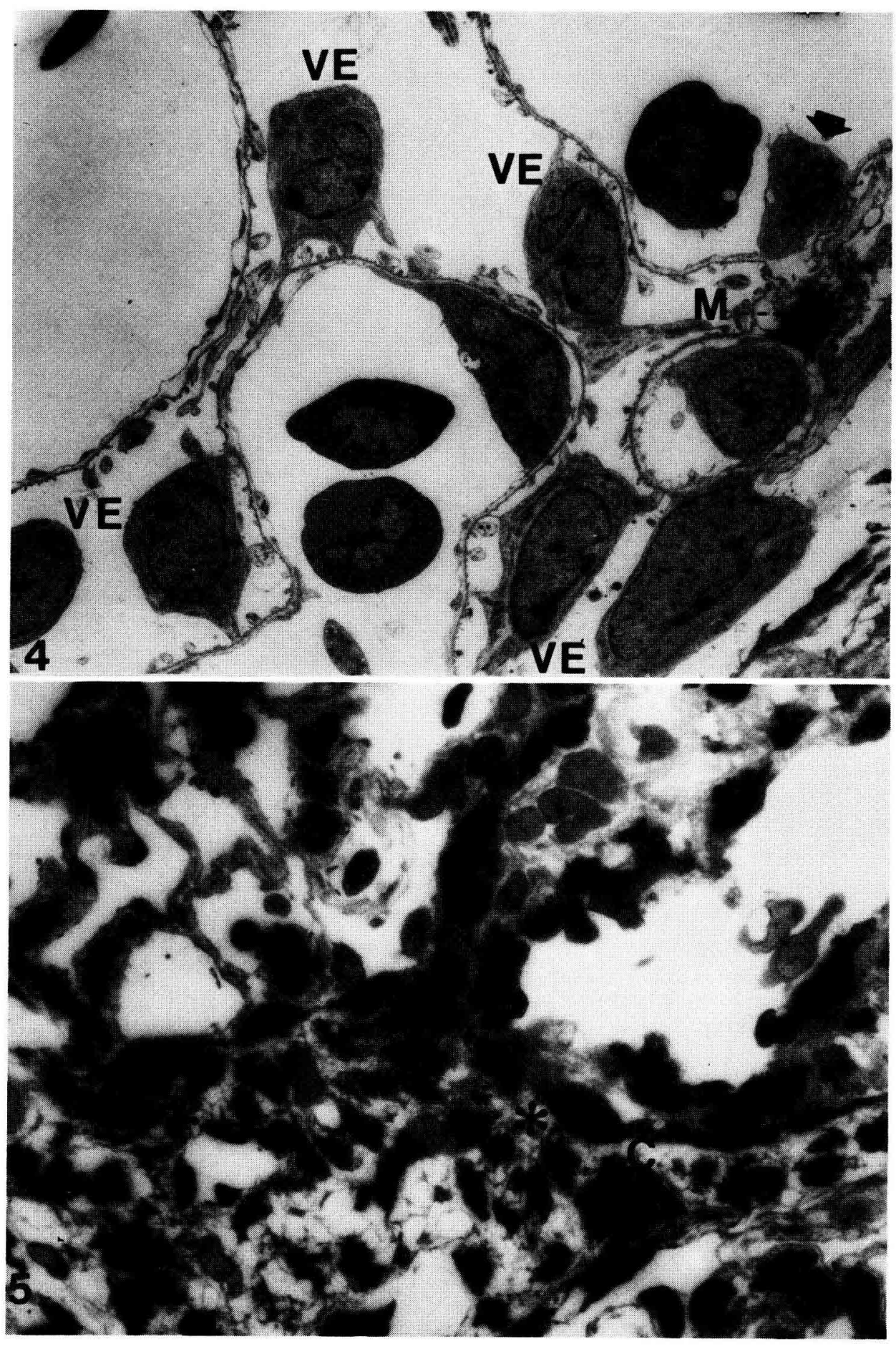


surrounded by a basal lamina. Mitoses were often noted in the cells enclosed within the trabeculae.

After short distances, the trabeculae became confluent (fig. 9) forming a conspicuous, compact cellular mass; as seen in single favorable sections on longitudinal planes or in serial sections on transverse planes, this mass extended uninterrupted distally through the upper pedunculum into the ovary (fig. 10). Upon entering the ovary, the mesonephric cell mass decreased gradually in compactness, became more expanded and terminated in a scattering of isolated cells (fig. 10). The mesonephric cells dispersing from the mass associated with the germinal cells (fig. 11) continuing to colonize the ovary in increasing numbers. This association resulted in the formation of small clusters of germinal and mesonephric cells crowding the ovarian stroma, especially in the ventral region of the organ.

\section{Thirty-eight through 41 days of fetal life.}

The ovaries of fetuses at these stages of development were prominent and protruded considerably into the coelomic cavity, being well demarcated from the ventral surface of the mesonephros to which they remained connected along the posterior surface and through the upper and lower pedunculi, now longer than in previous stages (fig. 12).

The giant glomeruli were considerably reduced in size. Thin capillaries had markedly restricted lumina and many were obliterated and undergoing fibrosis (fig. 13) ; fragments of the capsule persisted almost exclusively along the dorsal aspects of the glomeruli. Numerous trabeculae delimited by a well defined basal lamina, branched from the ventral aspects of the glomeruli into the surrounding stroma (figs 13 and 14). The trabeculae now consisted exclusively of epithelial cells departing from the capillary walls and the remnants of the capsule (figs 13 and 14). Adjacent cells here were tightly apposed against one another and frequently bound by desmosomes. The compact mass which resulted from the confluence of the trabeculae was more prominent and organized than in previous stages (fig. 15). Continuously surrounded by a basal lamina in its extraovarian segment, the mass traversed the proximal pedunculum (fig. 15) and reached the ovary where, without losing cohesiveness and, in fact, expanding considerably in diameter, it came to occupy the whole central region of the organ (fig. 12). The intraovarian portion of the mesonephric cell mass covered approximately 50 p. 100 of the surface of sections at, or close to, the equator of the organ, and constituted the most prominent ovarian component at these stages of development (fig. 12). It consisted prevalently of mesonephric cells tightly apposed against one another, and of scattered clusters of germinal cells which had been evidently trapped in the area by the colonization process. No intercellular compartments

FIG. 6. - Electron micrograph of an area analogous to that shown in fig. 5 showing in greater detail the exodus of mesangial $(M)$ and epithelial cells $(E)$ from the glomerulus. Note the absence of the glomerular capsule and the marked thickening of a segment of the capillary wall (arrow) $\times 3,300$.

FIG. 7. - Closely associated germinal and mesonephric cells (arrows) in the gonad of a 28-day-old embryo. $S M$, surface mesothelium. $1 \mu$ thick, Toluidine blue stained section $\times 620$. 

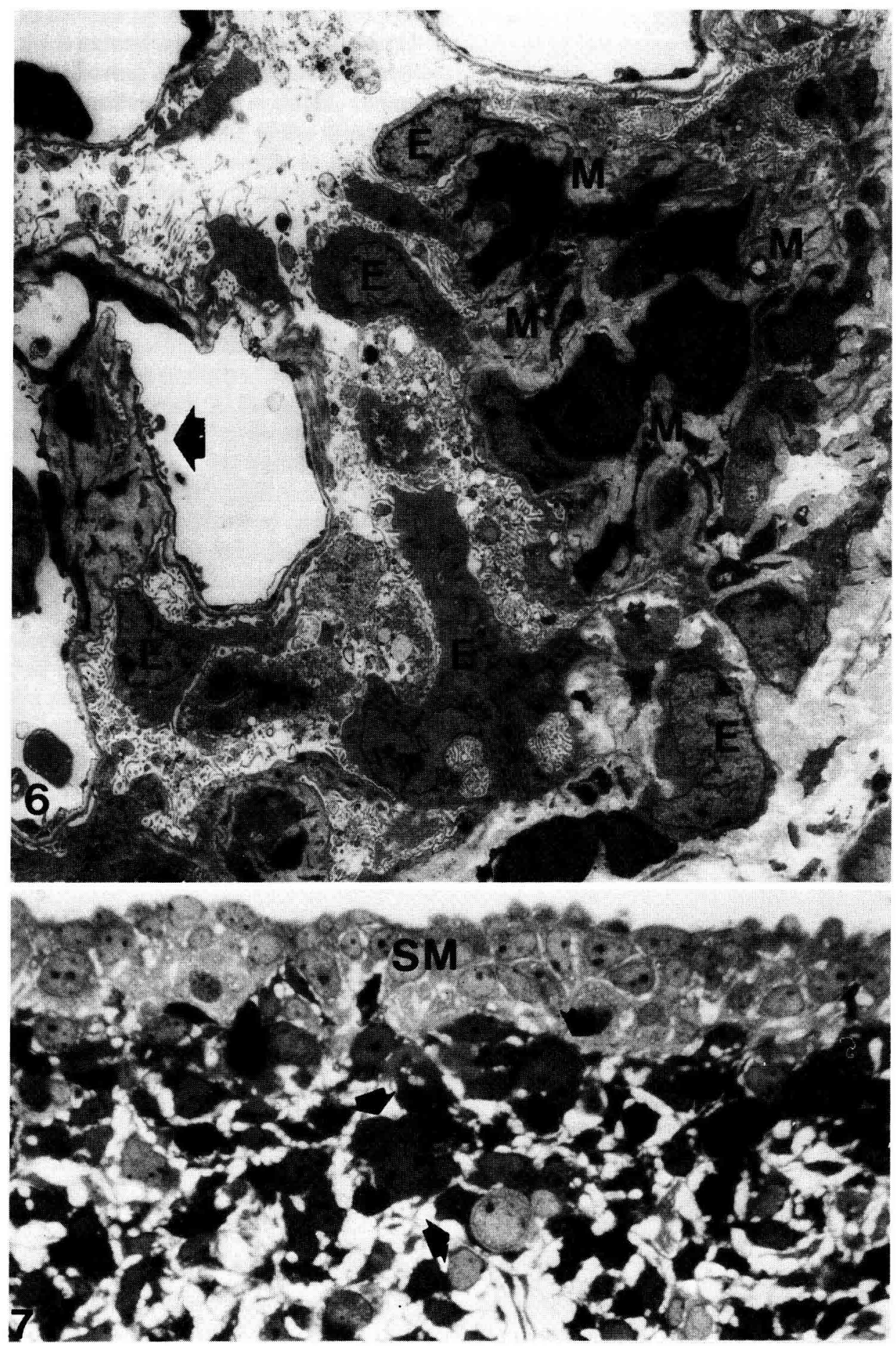
could be distinguished by light microscopy (fig. 12) ; by electron microscopy, adjacent cells appeared to be separated only by extremely narrow, slit-like spaces. The exclusion of mesenchymal elements and blood vessels made the compactness of the mass even more evident.

The dorsal aspects of the mass had a regular, sharply demarcated profile. In contrast, the ventral aspect was highly irregular due to presence of numerous mesonephric cells dispersing into the surrounding stroma where they associated with the germinal cells, now present in considerably increased numbers (fig. 16) ; as a result, the region of the ovary ventral to the mass appeared crowded by irregular cellular clusters consisting of one or more germinal cells surrounded by a peripheral layer of mesonephric cells (fig. 16). Mesonephric cells of adjacent clusters frequently established contact with one another, either by apposition of plasma membranes or by means of intercellular junctional devices; this resulted in the formation of larger cellular aggregates with highly irregular, ramified outlines (fig. 16).

Forty-five days of fetal life.

The giant glomeruli had completely regressed; fragments of capsules on the dorsal side and a few excretory tubules were the only remains of the original structures (fig. 17). Nevertheless, a prominent mass of mesonephric cells, many in mitosis, continued to extend from the region of the giant nephron to the center of the ovary (figs 17 and 18). As in previous stages, the roots of the mass consisted of slender trabeculae of epithelial cells ; however, the trabeculae now departed directly from the residual fragments of the glomerular capsule, the surviving excretory tubules and their basal laminae (fig. 17). The intraovarian portion of the mesonephric cell mass was very prominent (fig. 18) and appeared demarcated by a basal lamina, conti-

FIG. 8. - The mesonephros (M) and the ovary $(O)$ of a 34-day-old fefus. An elongated pedunculus connects the region of the giant nephron to the ovary. The giant glomerulus is in a relatively advanced stage of involution; the capillaries have thickened walls and restricted lumina, especially in the proximal region, and the whole ventral aspect of the glomerulus lacks the capsule (compare with the conventional glomeruli in the lower half on the micrograph). The trabeculae of cells mobilized from the giant glomerulus, and the cellular mass forming from their confluence are only fainfly visible on the right side of this low power micrograph but are shown in detail in the following micrographs. $1 \mu$ thick, Toluidine blue stained section $\times 65$.

FIG. 9. - Same fetus as in figure 8. Cellular trabeculae departing from the ventral aspect of the giant glomerulus (GG). Note the absence of the capsule. The confluence of the trabeculae and the most dorsal and cranial portion of the resulting cellular mass are on the right side of the micrograph. $1 \mu$ thick, Toluidine blue stained section $\times 650$.

FIG. 10. - A longifudinal view of the upper pedunculus $(\mathrm{P})$ and the proximal half of the ovary $(\mathrm{O})$ in a 34-dayold fetus, showing the mesonephric cell mass extending from the giant nephron (not included in the micrograph) into the ovary where the mass resolves in a scattering of isolated mesonephric cells which establish close association with the germinal cells (see following micrograph). MT, mesonephric tubules. $1 \mu$ thick, Toluidine blue stained section $\times 140$.

FIG. 11. - Germinal-mesonephric cell association in the ovary of a 34-day-old fetus. SM, surface mesothelium $\times 1,000$. 

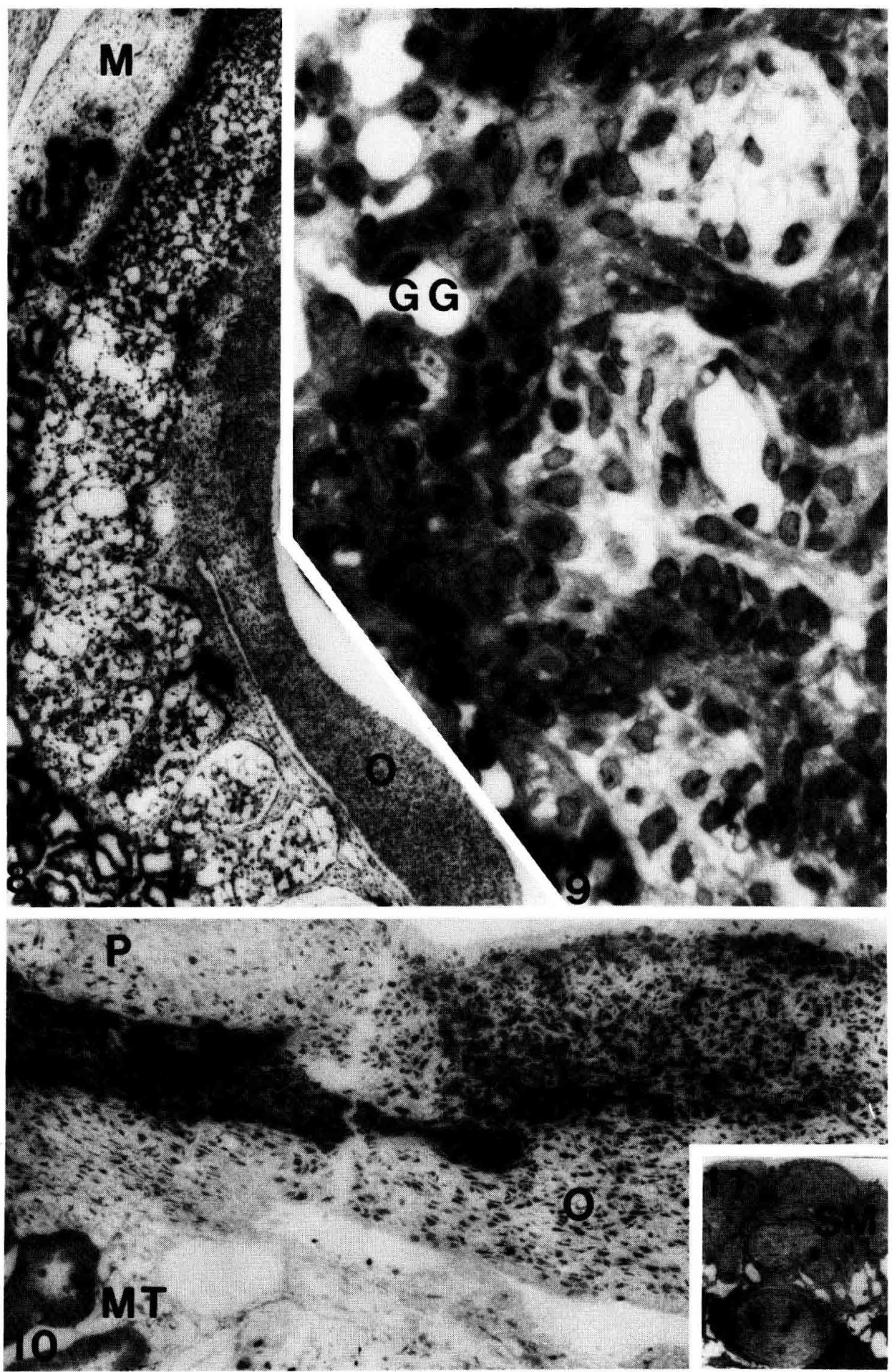
nuously on the dorsal aspect and discontinuously on the ventral side. The aggregates of mesonephric and germinal cells in the ovarian stroma ventral to the mass had further increased in number (fig. 18); most of them had coalesced and had assumed characteristics of short, cord-like formations (figs 18 and 19). The innermost ones were surrounded by a basal lamina and were occasionally continuous with the cells on the ventral aspect of the mesonephric mass (fig. 19). In these cases, the basal laminae of the two structures were also continuous.

\section{Forty-nine through 58 days of fetal life.}

The mass of mesonephric cells noted in previous stages continued to extend from the proximal region of the mesonephros into the ovary, entering into the organ from the most cranial portion of its dorsal margin due to modifications of the topographic relationship between the ovary and the proximal pedunculum (fig. 20). The characteristics of the mass had changed considerably as compared to previous stages, however, and signs of incipient atrophy were evident. The mass was thinner (figs 20 and 21) and was alimented only by a small number of trabeculae departing exclusively from the walls of the few remaining tubules of the giant nephron, now mostly obliterated and undergoing regression (fig. 21).

The stroma surrounding the tubules, the trabeculae and the cellular mass resulting from the confluence of the latter was undergoing transformation into a mature connective tissue characterized by a dense ground substance with prominent collagen bundles and numerous fibroblasts often organized in concentric layers (fig. 21). Connective tissue septa often infiltrated the trabeculae and the main cellular mass with consequent disorganization and hyalinization of these structures and degeneration of the mesonephric cells, some of which were still dividing, however (fig. 22). The surrounding stroma was littered by cellular debris undergoing phagocytosis by macrophages. While in 49 and 50-day-old fetuses, these changes were limited to the extraovarian portion of the mesonephric cell mass, at 58 days they had spread caudally

FIG. 12. - Longitudinal section through the central region of the ovary of a 41-day-old fefus. The upper pedunculus and conventional mesonephric glomeruli are seen on the right side. The center of the ovary is occupied by a solid cellular mass representing the terminal portion of the mesonephric cell mass extending from the giant nephron (see following micrographs). The ventral aspect of the mass is irregular due to dispersal of mesonephric cells into the surrounding stroma. The region of the ovary ventral to the mass is crowded by small clusters of germinal and mesonephric cells; these are shown in detail in figure $16.1 \mu$ thick, Toluidine blue stained section $\times 65$.

FIG. 13. - Advanced regression of the giont glomerulus in a 41-day-old fetus. Arrows point to trabeculae of epithelial cells departing from the ventral aspect of the glomerulus. $1 \mu$ thick, Toluidine blue stained section $\times 190$.

FIG. 14. - Ultrastructural appearance of the epithelial cell trabeculae from the giant glomerulus of a 41-dayold fetus. A few glomerular capillaries are seen in the lower right corner of the micrograph $\times 2,250$.

FIG. 15. - Cranial portion of the mesonephric cell mass of a 41-day-old fetus. Giant glomerular capillaries are shown at arrows. $T$, epithelial cell trabeculae. $1 \mu$ thick, Toluidine blue stained section $\times 230$. 

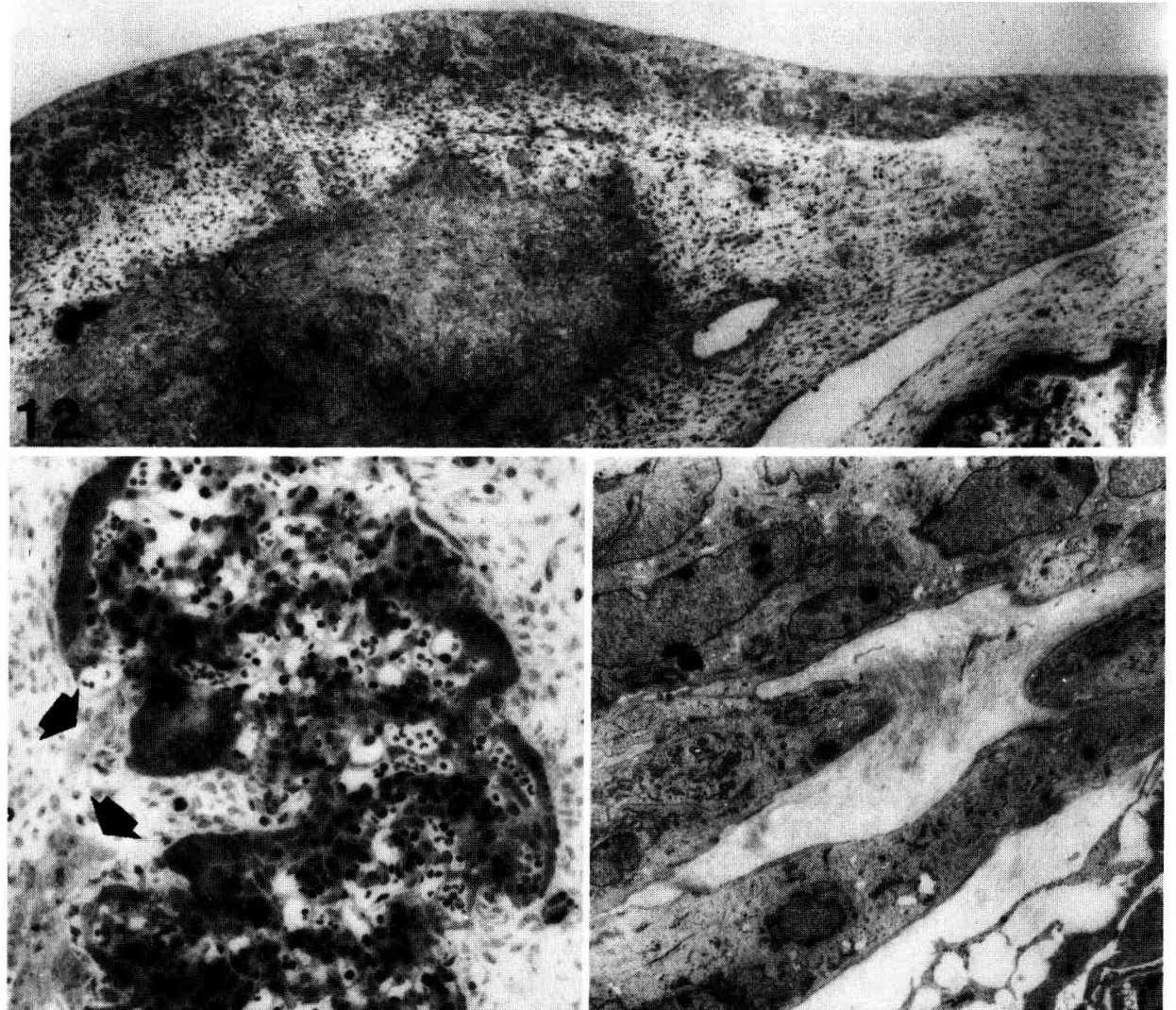
[Co +4.4$)$ $5+\infty 0^{\circ}$ te 8 13.

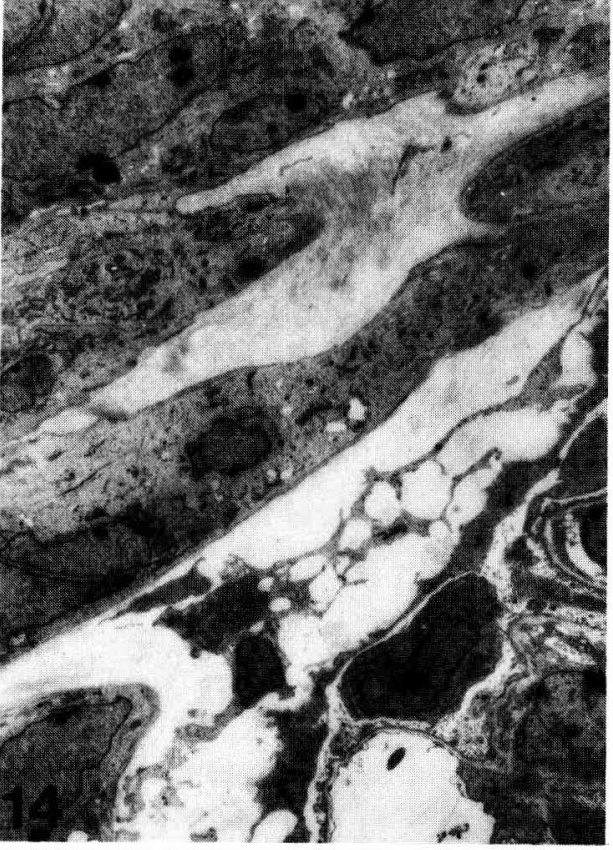

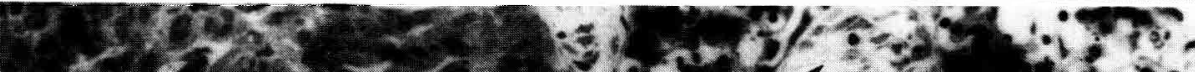

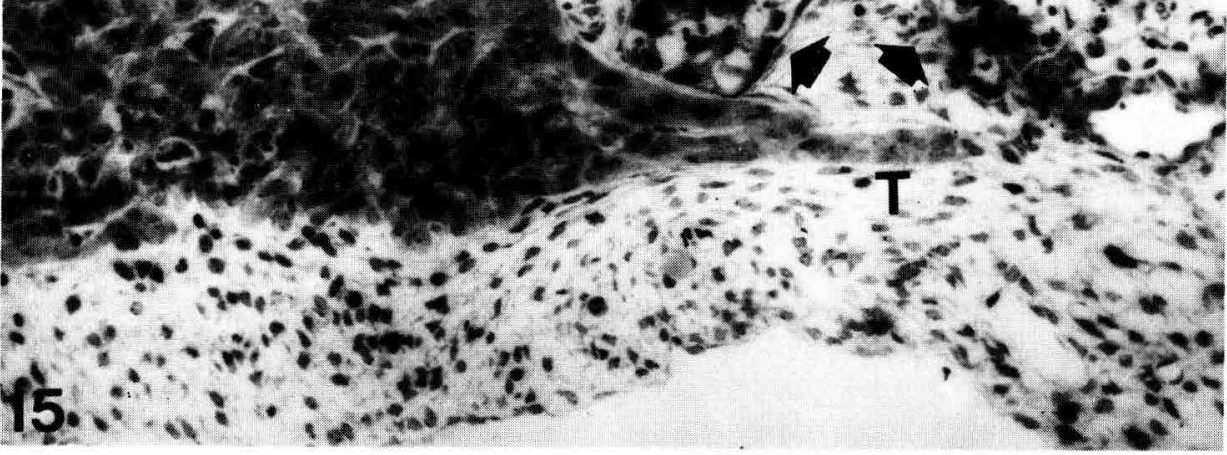


and ventrally to involve the intraovarian segment which appeared considerably reduced in size and completely surrounded by a thick investment of mature connective tissue (fig. 23).

In contrast, the aggregates of mesonephric and germinal cells peripheral to the mass were more developed and organized than in previous stages (fig. 23). They now had characteristics of full fledged ovigerous cords (fig. 24) consisting of germinal cells in different stages of differentiation, from mitotic oogonia to oocytes in meiotic prophase (fig. 25), surrounded by a thin investment of mesonephric, now prefollicle, cells (figs 24 and 25). The cords, separated by irregular septa of vascular connective tissue extended radially from the center towards the periphery of the ovary (fig. 23) where they terminated against the cells lining the surface (fig. 24). For the first time, thus, the ovary appeared demarcated into an inner region, the rudiment of the medulla, consisting mostly of connective tissue and the remnants of the mesonephric cell mass, and an outer region, the rudiment of the cortex, characterized by florid development of ovigerous cords of prefollicle and germinal cells (fig. 23).

Seventy through 73 days of fetal life.

Emission of epithelial cells from the atrophic mesonephric tubules no longer occurred and no evidence of any previous connection between the mesonephros and the ovary was detectable. The region dorsal to the ovary was entirely occupied by a thick connective tissue which, together with prominent blood vessels and numerous nerve fibers, extended deeply into the center of the ovary (fig. 26); in sections close to the equator, the region occupied by this connective tissue mass, the medulla, accounted for approximately 30 p. 100 of the organ. In the center of the medulla, the markedly atrophic, disorganized and hyalinized remnants of the previously prominent ovarian cell mass could still be distinguished (figs 26 and 27).

The cortex was crowded by radially oriented cords of prefollicle and germinal cells demarcated throughout by a continuous basal lamina and separated by septa of connective tissue and vessels emanating from the medulla (figs 26 and 28). The cords

FIG. 16. - Contiguous clusters of germinal $(G)$ and mesonephric cells in the ventral region of the ovary of a 41-day-old fefus (refer to fig. 12) $\times 1,400$.

FIG. 17. - A prominent mesonephric cell mass departing from the remnants of the capsule and excretory tubules of a nearly completely regressed giant nephron of a 45-day-old fetus. 0 , ovary, $1 \mu$ thick, Toluidine blue stained section $\times 120$.

FIG. 18. - Same ovary as in figure 17 in a deeper plane of section. The mass shown at its origin in figure 17 is now inside the ovary after having traversed the upper pedunculus (P). The mass is sharply demarcated along its dorsal aspect but highly irregular on the ventral side due to liberation of mesonephric cells into the surrounding ovarian stroma. Notice the numerous aggregates of mesonephric and germinal cells in the stroma ventral to the mass : many appear as cord-like formations. $1 \mu$ thick, Toluidine blue stained section $\times 180$.

FIG. 19. - Electron micrograph of a cord-like aggregate of germinal and mesonephric cells continuous with, or depariing from, the ventral aspect of the mesonephric cell mass. Forty-five-day-old fetus $\times 2,200$. 

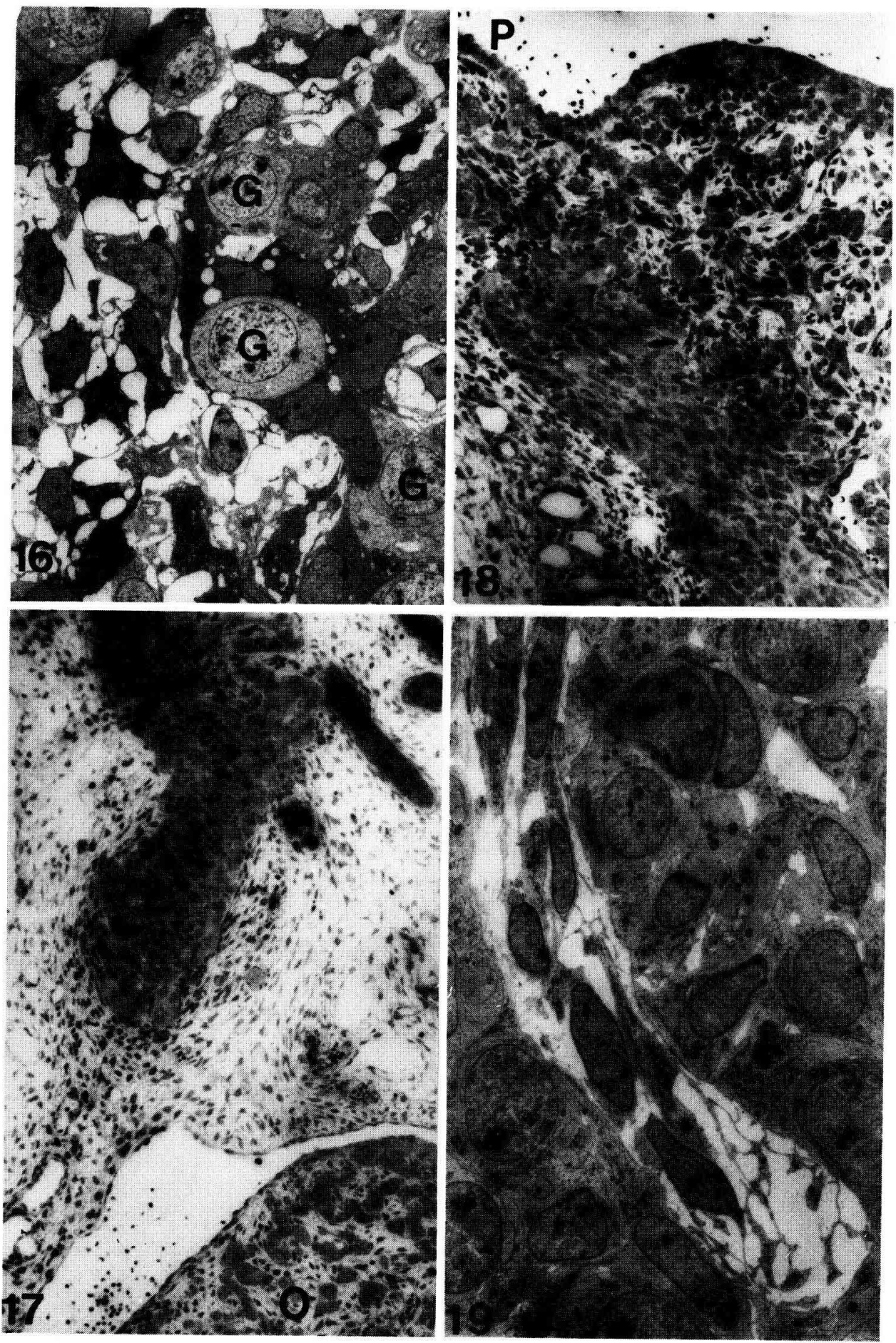
displayed marked differences in size and structural organization ; their innermost segments were generally wider and more highly organized than their peripheral portions (figs 26 and 28). A distinct polarization of the germinal cells within the cords was also evident; the innermost segments now predominantly contained prominent clusters of meiotic oocytes at synchronized stages of maturation, whereas their peripheral portions enclosed less differentiated germinal cells, including oogonia in mitosis. The innermost portions of the cords were frequently undergoing fragmentation accompanied by regression of their cellular constituents. These degenerating cord fragments were eventually reabsorbed in the thick connective tissue of the medulla.

\section{One hundred twenty through 145 days of fetal life.}

The medulla had expanded further and the cortex decreased proportionately ; in 120-day-old fetuses, the cortex accounted for less than 30 p. 100 of the surface of the ovary in sections close to the equator (fig. 29), and even less than that in the ovary at term (fig. 30). While the organization of the medulla appeared essentially unchanged from previous stages, profound modifications were noted in the cortex. Most of the ovigerous cords had disappeared and had been substituted by developing follicles (figs 31 and 32) ; remnants of the cords were seen only exceptionally and exclusively at the extreme periphery of the ovary (fig. 31), indicating that, just like any previous developmental and organizational process, also follicle formation had occurred gradually from center to periphery. The orientation of the follicles evoked that of the cords from which they had developed ; they were aligned over one another to form radial rows separated by septa of connective tissue and blood vessels (figs 31 and 32). The follicles varied considerably in size and organization (figs 30 , 31 and 32) and these differences were especially evident in the ovary at term (figs 30 and 32). The largest ones were localized in the innermost layers of the cortex, near the medulla, and the smallest at the extreme periphery of the cortex, just below the surface. In the ovary at term, the septa of the connective tissue extending between the

FIG. 20. - Fifty-day-old fefus. Mesonephric cell mass entering into the ovary through the proximal pedunculus. Notice the incipient thinning of the mass. $1 \mu$ thick, Toluidine blue stained section $\times 50$.

FIG. 21. - At 58 days, the mesonephric cell moss is still forming from the epithelial cells of the excretory tubules of the giant nephron in spite of their advanced regression. Notice the mature connective tissue present in the area and the numerous fibroblasts around the mass. $1 \mu$ thick, Toluidine blue stained section $\times 110$.

FIG. 22. - Extraovarian portion of the mesonephric cell mass being infiltrated by septa of mature connective tissue. Arrow points to an area of hyalinosis. In the lower center, a dividing epithelial cell is seen. Fifty-eight-day-old fetus. $1 \mu$ thick, Toluidine blue stained section $\times 550$.

FIG. 23. - Incipient differentiation of cortex and medulla in ovary of a 58-day-old fefus. The center of the medulla contains the mesonephric cell mass beginning to undergo atrophy and surrounded by a thick investment of mature, vascular connective tissue. The cortex is entirely occupied by radially oriented ovigerous cords. $1 \mu$ thick. Tolvidine blue stained section $\times 50$. 

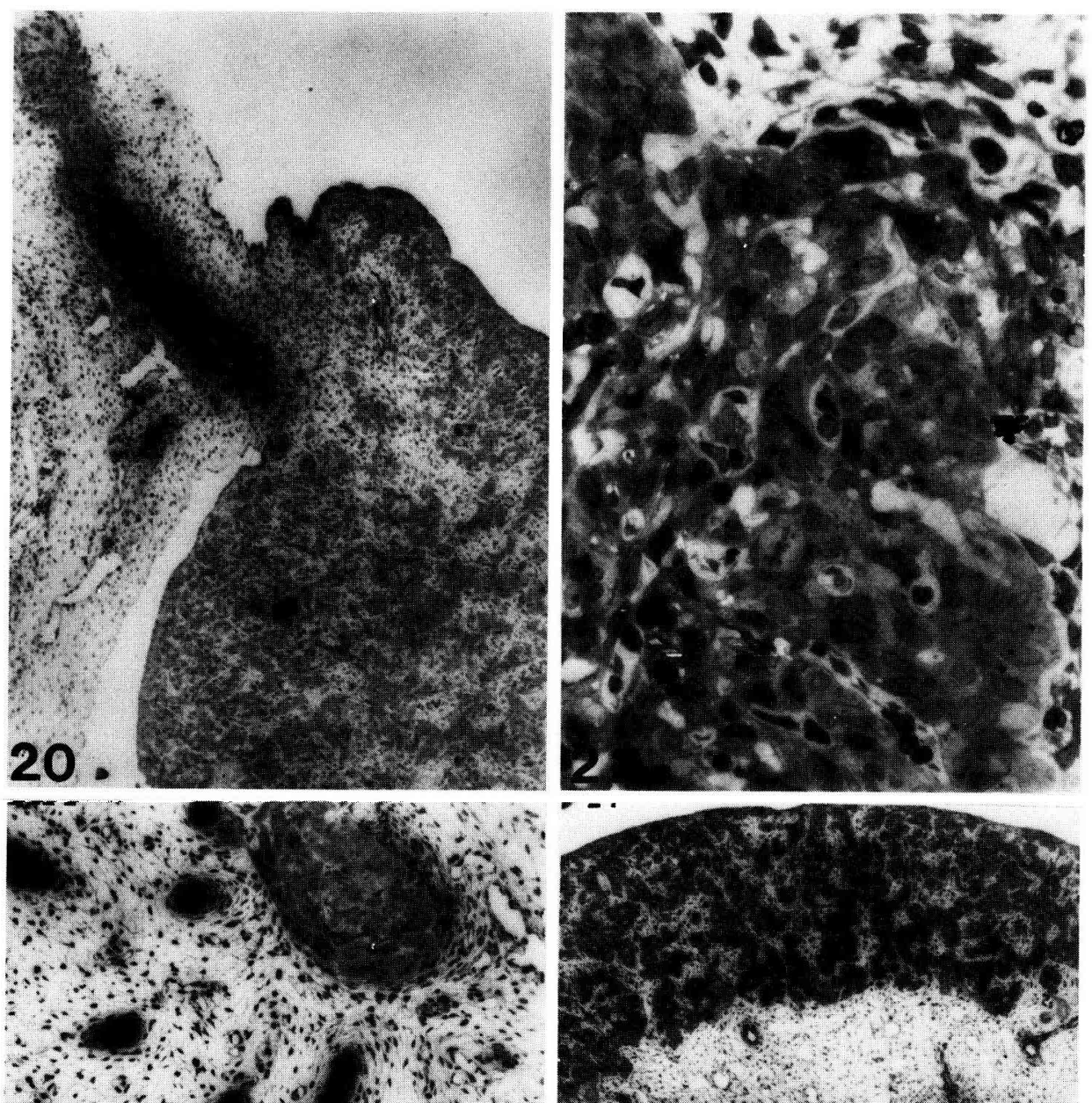

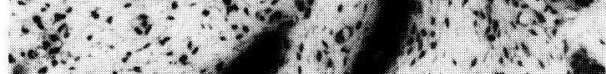

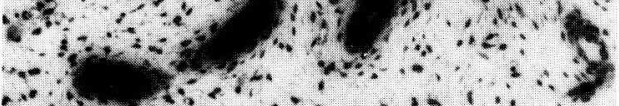

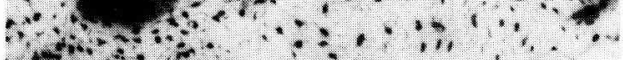
Fr:

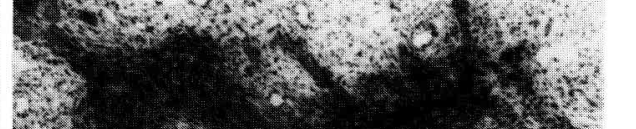
F

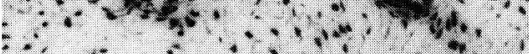

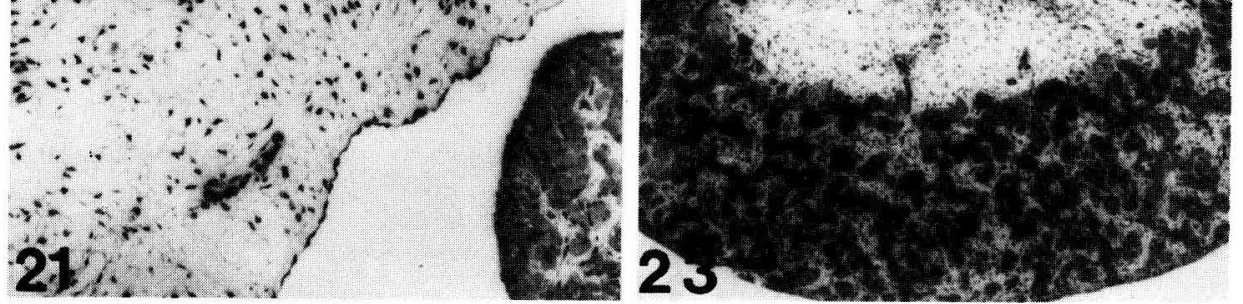


adjacent rows of follicles towards the surface of the ovary appeared to separate completely the most superficial follicles from the cells on the surface (fig. 32) ; the last of ovarian structures, the funica albuginea, had formed.

\section{Discussion.}

Our observations show that the sexually indifferent gonads and the ovaries of sheep embryos and fetuses are massively colonized by cells originating from a peculiar nephron in the proximal region of the mesonephros. The colonization process, which spans the period from day 24 to at least day 58 of development, involves at first sporadic cells reaching the ovary in an apparently non-organized fashion and, then, a prominent cellular mass with characieristics of increased organization. Within the gonad, the invasive mesonephric cells become closely associated with the germinal cells, maintaining this relationship throughout development; at the same time, transitory (the ovigerous cords) and definitive ovarian structures (follicles, cortex and medulla) become organized. We can, thus, conclude that, in the sheep, the mesonephros plays a fundamental role in the morphogenesis of the ovary as the source of the follicle cells and as one of the organizers of specific ovarian structures.

The participation of the giant glomerulus in the development of the sheep ovary had been noted already by Davies and Davies (1950) who reported that giant glomeruli in advanced stages of involution displayed on their ventral aspect a conspicuous mass of cells referred to by these authors as « rete blastema », which caudally become continuous with the "epithelial cords » of the gonad. Their observations fully reconcile with the findings of our study. While the basic changes which accompanied the involution of the giant glomerulus (mesangial hypercellularity, narrowing and obliteration of the capillaries, and generalized glomerular fibrosis) were similar to those observed in regressive mesonephric glomeruli of other species (Bernier and Beaumont, 1964 ; De Martino et al., 1977), the discontinuities of the glomerular cap-

FIG. 24. - Ovigerous cords in the ovary of a 58-day-old fetus. - The cords consist of numerous cells surrounded by attenuated mesonephric, now prefollicle, cells. The boxed area is shown at higher magnification in figure $25.1 \mu$ thick, Toluidine blue stained section $\times 190$.

FIG. 25. - The germinal cells in the ovigerous cords are at different stages of maturation and differentiation : an oogonium in mitosis and oocytes in meiotic prophase are clearly visible. $1 \mu$ thick, Toluidine blue stained section $\times 380$.

FIG. 26. - The dorsal region of the ovary in a 73-day-old fetus. Colonization by the mesonephric cells has ceased and the dorsal ligament now contains only a thick, mature connective tissue extending into the center of the medulla together with numerous blood vessels. The arrow points to the atrophic remnants of the mesonephric cell mass. $1 \mu$ thick, Toluidine blue stained section $\times 50$.

FIG. 27. - Atrophic and degenerating remnants of the mesonephric cell mass in the ovarian medulla of a 73-day-old fetus. $1 \mu$ thick, Toluidine blue stained section $\times 250$.

FIG. 28. - Ovigerous cords of a 73-day-old fetus. Notice the different degree of organization in the different segments of the cords, the most superficial of which are still forming. $1 \mu$ thick, Toluidine blue stained section $\times 200$. 


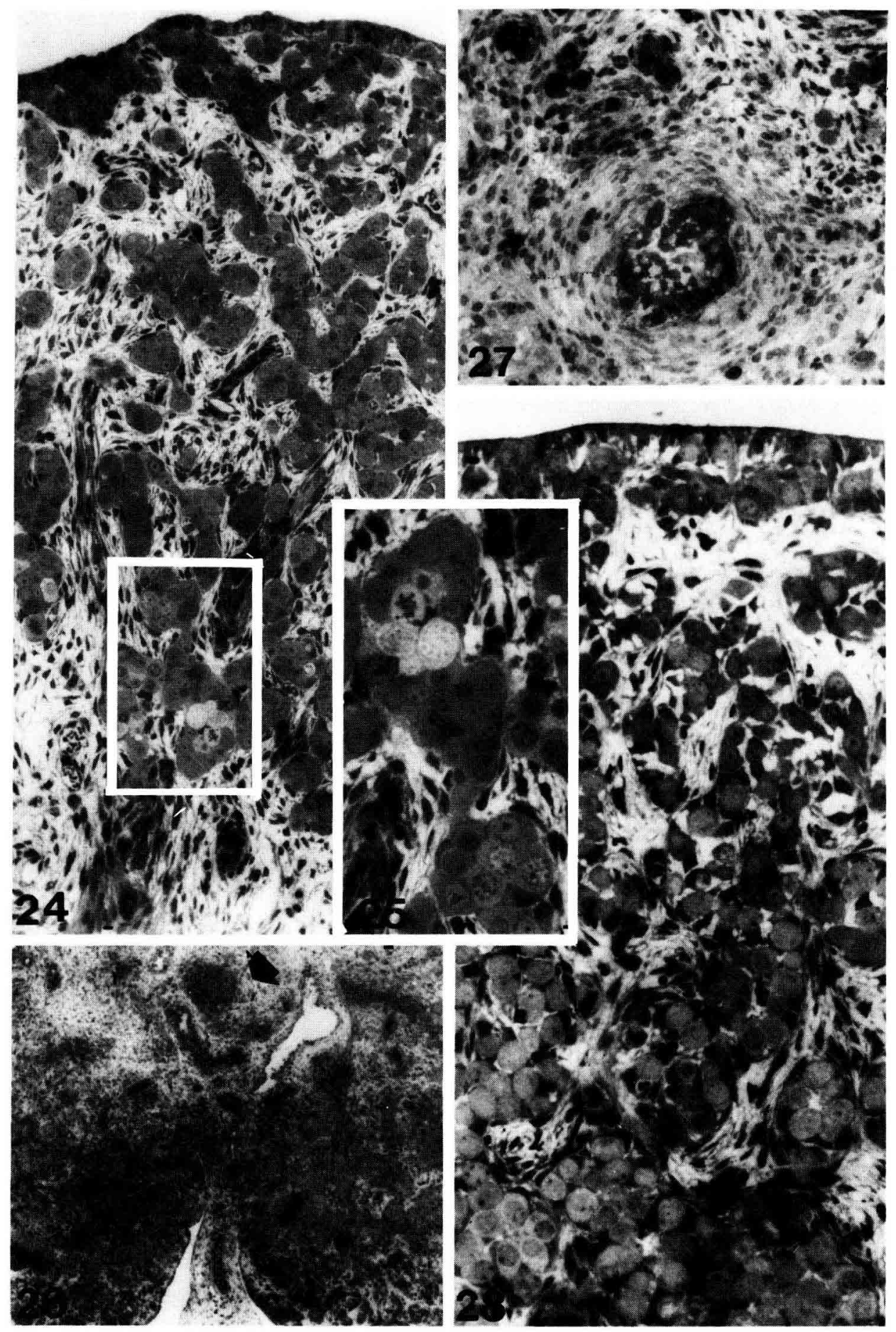


sule, the establishment of communications between the glomerulus and the surrounding stroma and, in particular, the massive mobilization of mesangial and epithelial cells were phenomena which, to our knowledge, had not been previously reported in the literature.

In early stages of the process (days 24 through 29 of felal life) and during its «non-organized phase », mesangial cells were the predominant type of cells mobilized from the glomerulus. They transmigrated from the glomerulus into the surrounding mesenchyme and then into the gonads mostly by ameboidism, as indicated by their highly distorted profiles and presence of numerous pseudopodia ; this reconciles with what is known on the nature and functional attitudes of the mesangial cells which are myoepithelial elements capable of contractility and locomotion required, among others, for their movement along the capillary walls (De Martino and Zamboni, 1966 ; Michielsen and Creemers, 1967 ; Zamboni and De Martino, 1968b ; De Martino et al., 1973 ; De Martino ef al., 1976). It is known also that the mesangial cells are capable of egressing by ameboidism from glomeruli maintained in culture especially when the capsule is discontinuous or altogether missing (Bernik, 1969), a situation similar to that noted in our study.

From day 34 to the end of the colonization process, the predominant, if not exclusive types of cells to be mobilized were the glomerular parietal and visceral espithelial cells to which tubular epithelial cells became associated in later stages. A these times, the invasive process occurred in the form of a "cellular continuum », i.e., a solid mass of cells extending uninterruptedly from the giant nephron into the ovary and made up of closely apposed cells mutually bound by approximation of plasma membranes, and desmosomes. Since ameboidism is not an attitude readily recognized in epithelial cells, especially when they are organized to form compact cellular masses delimited by a basal lamina, it is unlikely that locomotion was the mechanism by which they covered the considerable distance separating the target organ from their site of origin. In our opinion, transmigration more likely occurred by growth. The increment necessary for the mass of epithelial cells to reach the ovary, and to continue to expand within it, resulted very likely from a), the continuous addition to the mass of cells unfolding from the capsule of the glomerulus, the walls of the capillaries and the walls of the tubules, and $b$ ) the mitotic activity of the epithelial cells. The hypothesis that these were the two main factors responsible for the transmigration of the epithelial cells from the region of the giant nephron into the ovary, and that they operated synergistically, is supported by the observation that when the giant nephron had regressed completely, i.e., when the source of additional

FIGS 29 and 30. - Follicles in ovaries at 120 days of fetal development (fig. 29) and at ierm (fig. 30). Notice the gradual decrease in the size of the follicles from the innermost to the outermost layer of the cortex. $1 \mu$ thick, Toluidine blue stained section : fig. $29 \times 50$; fig. $30 \times 60$.

FIG. 31. - Follicles developing from a residual ovigerous cord in the ovary of a 120-day-old fefus. $1 \mu$ thick, Toluidine blue stained section $\times 300$.

FIG. 32. - Follicles of different sizes in the ovary at the end of fetal development (145 days). $1 \mu$ thick, Tolvidine blue stained section $\times 275$. 


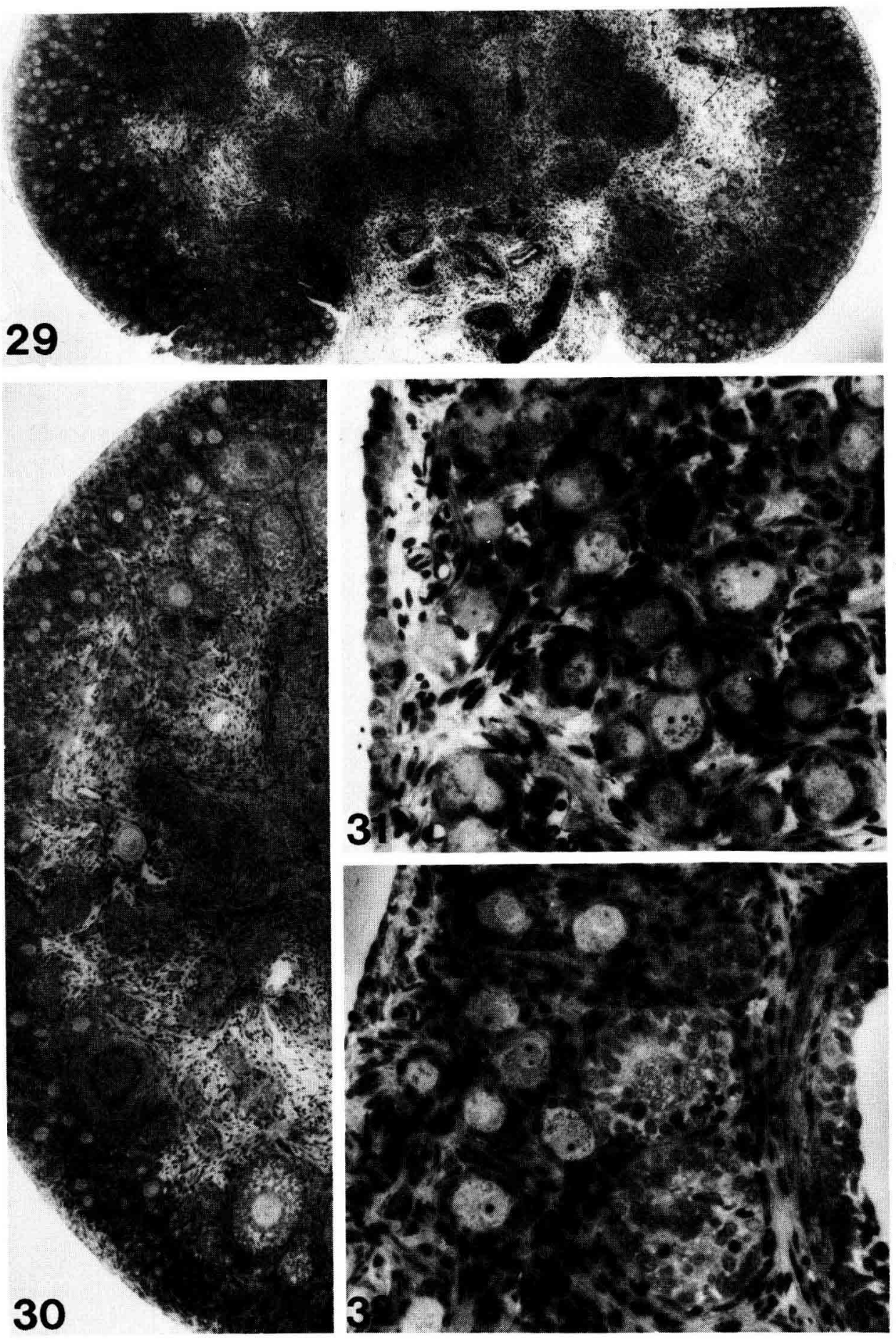


cells became exhausted, only the intraovarian portion of the mesonephric cell mass continued to expand due to unabated mitotic activity.

The main characteristic displayed by the mesonephric cells inside the ovary was to establish a relationship of close association with the germinal cells. This relationship was characterized by the germinal cells becoming completely encircled by the mesonephric cells, and by close apposition of the two cell plasma membranes ; in relatively late stages, the development of a basal lamina around germinal and mesonephric cells within the ovigerous cords further emphasized the close nature of this cellular association. Mesonephric-germinal cell association was also of a permanent nature since it was seen to accompany all phases of maturation and differentiation of the primordial germinal cells into oocytes. These considerations, and the fact that the germinal cells were not seen to establish analogous relationship with any other somatic cells, justifies the assertion that in the sheep the mesonephric cells are the precursors of the definitive follicle cells. In this regard, it is important to mention that the mesonephric cells invaded the gonads and established a close association with the germinal cells well before sexual differentiation and that these phenomena were noted in all embryos prior to day 31 of development, irrespective of their genetic sex; these observations indicate that the behavior of the mesonephric cells and their role in sheep gonadal morphogenesis is identical in both sexes. Studies on the development of the sheep fetal testis presently underway in our laboratory demonstrate that this is indeed the case.

To reach the gonad from the giant nephron, the mesonephric cells advanced along a cranio-caudal and dorso-ventral direction; they continued to progress along the same direction also within the gonadal region. The mesonephric cells which, at any given time, were most advanced along the direction of the invasive process, as well as the structures which they associated with, or were surrounded by, were always less differentiated and less organized than those behind them. An example of this dorsoventral and cranio-caudal gradient of organization was the gradual development of a basal lamina around the mesonephric cell mass, or the structures which originated from it, from when it first appeared around the trabeculae departing from the glomerulus (day 34 of fetal life) to the time it reached the most peripheral extremities of the ovigerous cords (day 73). An analogous gradient of organization was noted in the cords, the innermost portions of which were always more organized, and contained germinal cells more differentiated, than the outermost segments. Follicle development from the ovigerous cords also occurred gradually along the same direction and so did the differentiation of the primitive mesenchyme into mature connective tissue ; advancing cranio-caudally and dorso-ventrally from the region of the giant nephron toward and into the ovary, it brought about gradual atrophy and ultimately reabsorption of, at first, the extraovarian and, then, the intraovarian portion of the mesonephric cell mass. Continuing in its progressions toward the surface of the ovary, it resulted in the regression of the innermost segments of the cords, with consequent progressive expansion of the medulla and proportional diminution of the cortex.

The existence of a centrifugal wave of organization progressing from the giant glomerulus to the surface of the ovary indicates that the invasive process was not limited to providing the germ cells with a somatic cell investment, but also had the function 
of contributing to the organization of transient and definitive ovarian structures. It is, thus, possible to consider the mesonephros as one of the organizers of the ovary, a function that it obviously shares with other elements such as connective tissue and blood vessels.

Patterns of organization and differentiation analogous to those observed in this study do occur in other developing organs. The definitive kidney, for example, becomes organized as result of the invasion of the undifferentiated mesenchyme of the metanephric blastema by tubules of epithelial cells originating from the ureteral bud and advancing from the deepest portions of the blastema towards its periphery (Zamboni and De Martino, 1968a). At any given stage, just as in the sheep ovary, the nephrons in the deepest portions of the developing organ are more mature, organized and differentiated than those at the periphery.

The mesonephric cell mass noted in our study obviously corresponded to the system of tubules that classic authors observed to connect mesonephroi and fetal gonads in a variety of mammals (Waldeyer, 1870 ; Janosik, 1885, von Kölliker, 1898 ; von Winiwarter, 1900 ; Allen, 1904 ; von Winiwarter and Sainmont, 1908 ; Felix, 1912 ; Wichmann, 1912 ; Wilson, 1926 ; Gillman, 1948). Irrespective of differences of opinion as to the origin of these structures (see Introduction), these authors all considered these tubules simply as a « link » between the ovigerous cords on the one hand and the mesonephros on the other; their belief resulted from the assumption that the ovigerous cords formed as proliferative ingrowths of the mesothelial cells on the surface of the ovary. A different position was taken by Byskov and Lintern-Moore (1973), who reported that the immature mouse ovary is pervaded by a network of tubules originating from the Wolffian duct ; having observed that, in their intraovarian portions, these tubules enclosed germinal cells in various stages of maturation, these authors concluded that the follicle cells of the mouse ovary are mesonephric in origin. Our findings confirm the view of those authors who maintained that the tubular network extending between the mesonephros and the gonad is mesonephric in origin (Waldeyer, 1870 ; Janosik, 1885 ; von Kölliker, 1898 ; Winiwarter, 1900 ; Winiwarter and Sainmont, 1908 ; Byskov and Lintern-Moore, 1973) and support the validity of the conclusions of Byskov and Lintern-Moore (1973) that this mass is not a connection between the mesonephros and ovigerous cords but the very structure from which the cords and their somatic cells derive.

The intraovarian portion of the mesonephric cell mass which from days 41 to 58 of fetal life, constituted the most prominent component of the developing ovary obviously corresponded in volume, location and appearance to the alkaline phosphatase positive « central blastema » described by Gropp and Ohno (1966) in cattle fetal gonad and which these authors considered to be the source of ovarian follicle and interstitial cells and of testicular Sertoli and Leydig cells, a conclusion which, insofar as follicle cells is concerned, is in agreement with the findings of the present study. The possibility entertained by Gropp and Ohno (1966) that the " blastema » cells could derive from the wall of what they termed « a major mesonephric glomerulus » is fully confirmed by our findings, especially considering that, as mentioned before, the giant glomerulus is present also in the mesonephros of the cow (Brenner, 1915).

Finally, it seems important to mention that the observations made in our study 
would not have been possible had we not studied gonads and ovaries together with their mesonephroi, monitored closely spaced, sequential stages of development, serially sectioned the tissue, and correlated, whenever it was required, high resolution light microscopy with electron microscopy. The vastness of an organ such as the developing ovary and the complexity of its dynamic changes are such that, unless these precautions are taken, any attempt to study developmental patterns are likely to fail. In our opinion, the main factors which have contributed to maintain our knowledge on ovarian development stabilized at very precarious levels, are inadequate sampling and the use of inadequate techniques : it is evident, for example, that a process as vast and as complex as the development of the ovary can hardly be monitored on a few sections from minute areas of a few ovaries prepared for electron microscopy. It is not to be excluded that, if more accurate and detailed studies were to be performed, the mesonephros could be found to play a major role in the development of ovaries of most, if not all, mammals.

4th Workshop on « Development and maturation of the reproductive organs and functions $》$ Luynes, France, octobre 1978.

Acknowledgments. - This study was supported by a USPHS research grant (\# HD09913-02) to L. Zamboni.

Résumé. Nous avons étudié en microscopie photonique sur des coupes semi-fines et en microscopie électronique, les gonades indifférenciées, les ovaires et les mésonéphroi d'embryons et de fœetus de brebis âgés de 24 à 145 jours (date du terme).

Entre le $24^{\mathrm{e}}$ et le $58^{\mathrm{e}}$ jour, les gonades indifférenciées et les ovaires sont massivement envahis et colonisés par des cellules provenant d'un néphron particulier situé au niveau du tiers céphalique du mésonéphros et dénommé « géant», en raison de ses grandes dimensions. Le processus de mobilisation des cellules survient en même temps que se produit l'involution du néphron géant. Ce processus englobe les cellules mésangiales et épithéliales du glomérule et aussi, plus tardivement, les cellules épithéliales de la paroi des tubes excréteurs. D'une façon sporadique d'abord, et ensuite sous la forme d'une masse importante et compacte, ces cellules quittent leurs sites d'origine, progressent à la fois dans le sens cranio-caudal et dorso-ventral ef envahissent la gonade. Les cellules mésonéphriennes établissent alors avec les cellules germinales, qui dans le même temps atteignent la gonade et s'y développent, une association étroite et permanente. Au cours du développement de l'ovaire, cette association entre les cellules mésonéphriennes et germinales montre toutes les caractéristiques d'une organisation croissante ; au début, seules quelques cellules isolées sont associées, puis progressivement, des amas cellulaires se forment et enfin, se constituent les cordons ovigères, structures allongées, formées de cellules mésonéphriennes et germinales, délimitées par une membrane basale et à partir desquelles se développent les follicules.

Nos observations démontrent que, chez la brebis, le mésonéphros joue un rôle fondamental dans la morphogenèse de l'ovaire ; il est la source des cellules folliculeuses fournies à la gonade et l'un des organisateurs des structures spécifiques de l'ovaire.

\section{References}

ALLEN B. M., 1904. The embryonic development of the ovary and testis of the mammals. Am. J. Anat., 3, 89-146.

BERNIER N., BEAUMONT A., 1964. Structure et régression du mésonéphros du fœutus de lapin. C. R. Soc. Biol., 158, 2227-2230. 
BERNIK M. B., 1969. Contractile activity of human glomeruli in culfure. Nephron, 6, 1-10.

BOOKHOUT C. G., 1945. The development of the guinea pig ovary from sexual differentiation to maturity. J. Morphol., 77, 233-263.

BRAMBELL F. W. R., 1927. The development and morphology of the gonads of the mouse. I. The morphogenesis of the indifferent gonad and of the ovary. Proc. roy. Soc. London, Ser. B., 101, 391-409.

BRENNER J. L., 1915. The mesonephric corpuscle of the sheep, cow and deer. Anat. Rec., 10, 1-6.

BRENNER J. L., 1916. The interrelationship of the mesonephros, kidney and placenta in different classes of animals. Am. J. Anot., 19, 179-204.

BYSKOV A. G., LINTERN-MOORE S. M., 1973. Follicle formation in the immature mouse ovary. The role of the rete ovarii. J. Anat., 116, 207-217.

DAVIES J., DAVIES D. V., 1950. The development of the mesonephros of the sheep. Proc. zool. Soc. London, 120, 95-112.

DE MARTINO C., ZAMBONI L., 1966. A morphologic study of the mesonephros of the human embryo. J. Ultrastruct. Res., 16, 339-427.

DE MARTINO C., ACCINNI L., PROCICCHIANI G., 1973. Ultrastructural study on contractile structures in mammalian nephrons. Their development in the metanephros of human embryos. Z. Zellforsch, 140, 101-124.

DE MARTINO C., NATALI P. G., ZAMBONI L., ACCINNI L., 1976. Ultrastructural study of mesangial cells and their relationship to smooth muscle cells of glomerular arterioles. Contr. nephrol., 12, 17-24.

DE MARTINO C., ZAMBONI L., ACCINNI L., 1977. Fine morphology of regressing human mesonephric nephrons. Exp. molec. Path., 26, 169-183.

EVERETT N. B., 1943. Observational and experimental evidences relating to the origin and differentiation of the definitive germ cells in mice. J. exp. Zool., 92, 49-91.

FELIX W., 1912. The development of the urogenital organs. In KEIBEL F., MALL F., Manual of Human Embryology, Vol. 2, 752-979, Lippincott, Philadelphia.

FISHEL A., 1930. Über die Entwicklung der Keimdrüsen des Menschen. Z. Anat. Entwickl. Gesh., 92, 34-72.

GILLMAN, J., 1948. The development of the gonads in man, with a consideration of the role of fetal endocrines and the histogenesis of ovarian tumors. Contrib. Embryol. Carnegie Found., 32, 82-131.

GONDOS B., 1969. Ultrastructure of the germinal epithelium during oogenesis in the rabbit. J. exp. Zool., 172, 465-480.

GROPP A., OHNO S., 1966. The presence of a common embryonic blastema for ovarian and testicular parenchymal (follicular, interstitial and fubular) cells in the cattle, Bos taurus. $Z$. zellforsch., 74, 505-528.

GRUENWALD P., 1942. The development of the sex cords in the gonads of man and mammals. Am. J. Anat., 70, 359-397.

JANOSIK J., 1885. Histologische-embryologische Untersuchungen über das Urogenital System. Sitzungsberg. Kais. Akad. Wissensch. Wien, 91, 97-199.

KÖLLIKER von A., 1898. Über die Markkanäle und Markstränge in den Eierstöcken junger Hundinnen. Verhandl. Anat. Gesellsch. Jena.

LEESON T. S., 1960. Electron microscopy of the developing kidney : An investigation into the fine structure of the mesonephros and metanephros of the rabbit. Am. J. Anat., 94, 100-106.

MERCHANT H., 1975. Rat gonadal and ovarian organogenesis with and without germ cells - An ultrastructural study. Dev. Biol., 44, 1-21.

MICHIELSEN P., CREEMERS J., 1967. The structure and function of the glomerular mesangium, 5772. In DALTON A. J., HAGUENAU F., The ultrastructure of the kidney. Acad. Press, New York.

PELLINIEMI L. J., 1975. Ultrastructure of the early ovary and testis in pig embryos. Am. J. Anat., 144, 89-112.

PETERS H., PEDERSEN A., 1967. Origin of follicle cells in the infant mouse ovary. Fertil. Sferil., 18, 309-313.

PINKERTON J. A. M., McKAY D. G., ADAMS E. C., HERTIG A. T., 1961. Development of the human ovary. A study using histochemical techniques. Obst. Gynec., 18, 152-181. 
TORREY T. W., 1945. The development of the urogenital system of the albino rat. II. The Gonads. Am. J. Anat., 76, 375-397.

VAN WAGENEN G., SIMPSON M. E., 1965. Embryology of the ovary and testis in Homo sapiens and Macaca mulatta. Yale Univ. Press, New Haven.

WALDEYER W., 1870. Eierstock und Ei. Englemann, Leipzig.

WEAKLEY B. S., 1969. Differentiation of the surface epithelium of the hamster ovary. An electron microscopic study. J. Anat., 105, 129-147.

WICHMANN S. E., 1912. Über die Enstehung der Urogenital verbindung und die Bedeutung der Müllerschen Geniłalgänge bei den Saügetieren. Anat. Hefte, 45, 629-695.

WILSON K. M., 1926. Correlation of external genitalia and sex glands in the human embryo. Carnegie Inst. Contrib. Embryol., 18, 23-30.

WINIWARTER von H., 1900. Recherches sur l'ovogenèse ef l'organogenèse de l'ovaire des mammifères (lapin et homme). Arch. Biol., 17, 33-199.

WINIWARTER von H., SAINMONT G., 1908. Nouvel les recherches sur l'ovogenèse ef l'organogenèse de l'ovaire de mammifères (chat). Arch. Biol., 24, 373-431.

WITSCHI E., 1951. Embryogenesis of the adrenal and the reproductive glands. In PINCUS G., Rec. Progr. Hormone Res., 6, 1-27, Acad. Press, New York.

WITSCHI E., 1956. Development of verfebrates. Saunders, Philadelphia.

WITSCHI E., 1962. Embryology of the ovary. In The ovary. Int. Acad. Pathol. Monogr., Vol. III, 1-10, Williams and Wilkins, Baltimore.

ZAMBONI L., DE MARTINO C., 1968a. Embryogenesis of the human renal glomerulus. I. A histological study. Arch. Pathol., 86, 279-291.

ZAMBONI L., DE MARTINO C., 1968b. A re-evaluation of the mesangial cells of the renal glomerulus. Z. Zellforsch., 86, 364-383. 